\title{
The Emperor's New Clothes: The Uncertain Fate of Equal Employment Opportunities in the New Zealand Public Sector, 1988-1992
}

\author{
Pat Walsh* and John Dickson**
}

\section{Introduction}

During the last decade, equal employment opportunities (EEO) has moved firmly onto the agenda in the New Zealand public sector, as in other countries. Legislation governing the operation of central, regional and local government and the state's trading enterprises contain a "good employer" obligation which requires chief executives to implement EEO programmes. The allocation of resources to EEO, the appointment of EEO co-ordinators, the development of EEO programmes and the explicit consideration of the EEO implications of wider policies and decisions have all become regular elements of the management of public sector organisations. Long-serving employees could not but identify the development of EEO as one of the major changes of the last decade.

And yet for all that apparent change, there remains a widespread perception in New Zealand that the EEO agenda has promised more than it has delivered. Recently, one EEO consultant was moved to write that EEO has reached a "crisis point". She argued that "a series of setbacks over the past 18 months has left EEO scrambling for political, financial and moral support, even in the regulated government sector. EEO practitioners grappling for direction continue a rear guard action with little success" (Hamid, 1992: 4). Studies of the impact of the good employer obligation on EEO in the public sector have also reached pessimistic conclusions (Tremaine, 1991; Messervy, undated). A recent report by the EEO Section of the State Services Commission, which has a statutory responsibility to "promote, develop and monitor" EEO in the public service, shared this pessimism. The report noted the lack of progress of EEO subject groups in public service employment and their continued under-representation in management and upper-income positions. The report concluded that despite considerable progress in some departments and in some areas "the evaluation of progress in EEO across the public sector shows that EEO needs to be more fully embedded into the culture and operation of the public service. . . . the role and influence of EEO remains fairly circumscribed" (State Services Commission, 1992: 17).

* Victoria University of Wellington

The authors would like to thank the Faculty of Commerce and Administration and the Internal Research Committee, both of Victoria University of Wellington, for their support for this project. They are grateful also to the nine government departments, and particularly their EEO co-ordinators, who helped them with their research. 
The aim of this paper is to analyse the development of EEO as a political and industrial issue in the New Zealand public sector since the early 1980s. It seeks to understand how the issue of EEO unfolded over time, the manner in which it acquired both political and industrial resources, and the process by which it lost them. It also seeks to understand the bit in the middle - the programmes which were established in the early days when EEO appeared to be becoming entrenched in the management of government departments.

This study examines the fate of EEO in nine government departments for $1988 / 89,1989 / 90$ and 1990/91. It is based on an analysis of the EEO Management Plans in the nine departments, their progress reports on the achievement of the Plans and statistical reports on the employment of EEO subjects. The results are presented in aggregate terms. It was not our intention to provide a comparative report card on progress towards EEO in different departments. Nor did we aim to track annual variations within and across departments. Our interest is in understanding the character of EEO Management Plans, the internal struggle between competing models of EEO which they reflect and sustain, and the manner in which the issue of EEO unfolded in the New Zealand public sector. The aim is to explain how by the end of this period, EEO, seemingly so strongly supported and promoted, had in fact lost ground in the management of the public sector. This process is best understood in terms of the location of EEO within a wider institutional context, which created opportunities for the advancement of EEO at the same time as it set limits to what could be achieved.

\section{Competing models of EEO: liberal, radical and transformational}

Jewson and Mason (1986) contrast two models of EEO, one liberal and one radical, as drawing upon "quite different notions of society, of the individual and of the role of the state" (1986: 308). The liberal model is grounded in classical liberalism's "abhorrence of traditional privilege, self-perpetuating elites and arbitrary social restraints" (p.314). The liberal concern is with labour market procedures. Liberalism looks for the free and open operation of a competitive labour market in which advancement is dependent only on merit, which is seen, crucially, as an objective and individual attribute. The purpose of an EEO policy is to ensure that impediments to a freely operating labour market are removed, and that individuals compete there equally, with outcomes decided by relative merit.

The radical model of EEO eschews the liberal focus on procedure in favour of an emphasis upon labour market outcomes. As Adams (1990: 5) observes, the liberal model "relies heavily on interpretations of fair procedures from within the same ideas, structures and processes which have generated the unfair situations in the first place. To establish fair procedures often only increases access to further unfair procedures, covert or overt". Moreover, says Adams, the introduction of fair procedures today does nothing to remedy the harm done by unfair procedures in the past. Even more fundamentally, to supporters of the radical model, liberal notions of merit as an objective and individual attribute "contain and conceal a series of value judgements" (Jewson and Mason, 1986: 315). Poiner observes that merit is neither neutral nor context-free, and "reflects the interests and values of the evaluators" (1991: 4). Merit, in the radical model, is a socially constructed concept, reflecting the ability of powerful groups in the society to define what abilities, skills, and 
knowledge will be valued over others. Possession of these abilities, skills and knowledge is not randomly distributed in the society, but is systematically biased in favour of particular social groups (Adams, 1990: 15; Webb and Liff, 1988: 546; Jewson and Mason, 1986: 314). Therefore, the group is the conceptual basis of the radical model of EEO. It seeks to remove labour market impediments to the equal advancement of target groups. Thus, for radicals "the absence of a fair distribution is, ipso facto, evidence of unfair discrimination" (Jewson and Mason, 1986, p.315), and is itself justification for labour market intervention to ensure fair outcomes. The liberal model, of course, recommends the minimum degree of intervention necessary to remedy specific imperfections in labour market operation.

Jewson and Mason observe that the liberal and radical models are led to quite different methods of implementing EEO policies. Liberals promote a Weberian solution - the bureaucratisation of procedures and their universal application to ensure that "the remnants of tradition, custom, charisma and personal patronage in employment practice are subordinated to the discipline of formal rules and regulations" (p.318). To ensure the effectiveness of EEO policies, liberals take a positive action approach, designed to eliminate impediments to the freely operating labour market. Positive action policies include changes to a wide range of personnel practices, recruitment, selection and promotion, as well as other policy changes such as provision of child-care facilities, EEO awareness training to change workplace attitudes, support for domestic leave and so forth. Webb and Liff comment that this approach locates the source of labour market discrimination narrowly within personnel and human resource management procedures, and takes no account "of either the differing bases of exclusion from occupations or the importance of economic and organisational contexts for the outcomes of policy" (1988: 545).

Radicals have less faith in the efficacy of reformed human resource management procedures. For them, the key requirement is the politicisation of decision-making in a conscious effort to promote the interests of target groups. Radicals favour positive discrimination. This "entails the deliberate manipulation of employment practices so as to obtain a fair distribution of the deprived or disadvantaged population within the work-force" (Jewson and Mason, 1986, p.322). Positive discrimination policies might include specific employment quotas, varying entry requirements or different criteria for performance assessment.

Recent analysis has focused on the limitations of the radical model's emphasis upon labour market manipulation to ensure parity of outcomes. Cockburn (1989) is critical of Jewson and Mason's liberal/radical framework. She argues that "this dichotomous schema is a strait-jacket we need to escape if we are to understand the equal opportunities movement and its potential place in contemporary politics" (p.215). Cockburn found little support for the radical prescription of positive discrimination among target groups in her case-study. "Moving the goalposts" was seen as unfair itself, and as likely to divide target groups (and possibly stimulate a conservative backlash). Even more importantly, it was criticised for accepting as given the character of the organisations that generate discrimination and exploitation. Cockburn, therefore, rejects the implied identification of the radical model with progressiveness. The radical model "seeks to give disadvantaged groups a boost up the ladder, while leaving the structure of that ladder and the disadvantages it entails just as before" (p.217). Similarly, Poiner (1991: 4) describes EEO as "profoundly assimilationist", 
involving subordination to the values of a masculinity model which devalues what women regard as important.

This critique of both the liberal and radical approaches to EEO has been accompanied by growing disenchantment with what either of them can achieve. Cockburn claims that "equal opportunities is widely seen as a tool of management that has sanitised and contained the struggle for equality" (1989: 213). Others see the effectiveness of EEO policies as limited to assisting the employment prospects of full-time permanent workers, but as having little impact upon racial and gender-based occupational segregation, still less upon the marginalised status of workers with disabilities (Sullivan, 1991), and as failing to lead to any substantial improvement in the employment conditions and job security of non-standard employees - part-time, temporary and casual workers and homeworkers (Webb and Liff, 1988; Poiner, 1991).

Critics of the liberal and radical models have advocated an alternative approach to EEO, one which "would address the terms on which jobs are currently offered and the ways in which jobs are structured" (Webb and Liff, 1988: 547). Cockburn has proposed a transformational model of EEO, one which replaces the liberal/radical dichotomy with the notion of an EEO agenda of shorter or greater length. The shorter agenda entails the modifications to personnel and human resource management policies which are central to the liberal model. The longer agenda entails "a project of transformation" for organisations, which incorporates the radical agenda of fair outcomes for target groups, but which also "brings into view the nature and purpose of institutions and the processes by which the power of some groups over others in institutions is built and renewed ... it also looks for change in the nature of power, in the control ordinary people of diverse kinds have over institutions, a melting away of the white male monoculture" (p.218).

\section{Creating the EEO alliance in the New Zealand public sector}

The fate of EEO in the New Zealand public sector was tied to the intersection of two separate and opposing agendas for change. On the one hand, an EEO agenda promoted the remedying of labour market discrimination by the implementation of policies constraining and channelling managerial discretion. This reform programme ran up against a managerialist restructuring agenda which aimed to reshape the public sector in the image of successful private sector firms and to do away with bureaucratic restrictions on managerial discretion. "Let the managers manage" was the catch-cry. It was claimed that bureaucratic restrictions had stifled public sector managers and impaired efficiency.

The two agendas were not easily reconciled. They were informed by different values, oriented to the achievement of conflicting objectives and their prescriptions for managerial practices were markedly at variance. The development of EEO in the New Zealand public sector, during a period of comprehensive managerialist-driven restructuring, reflected to a considerable degree the ability of its advocates to hitch the cause of EEO to that of managerialism. But it also reflected the acquisition of independent resources by EEO advocates, and their ability to resist the degeneration of EEO to the status of a mere servant of managerialism. The shifting fortunes of the EEO agenda and its subtle interplay with 
managerialism underscore the complexity of the policy process and serve as a warning against monocausal explanations of policy outcomes.

The emergence of EEO as an issue preceded the managerialist restructuring agenda. The initial progress and long-term fate of EEO illustrates the importance of the sequential posing of issues and acquisition of resources. This allows constituencies for particular interests to become established, and increases their ability to resist threats from seemingly stronger but later developing oppositional causes. The industrial and political ground gained by EEO in its early years conferred upon it resources which meant it could not easily be dismissed by the advocates of managerialism.

EEO became industrially and politically salient in the first half of the 1980 s. This was in part a response to the evident inadequacy of existing legislation in New Zealand. Legislation to prohibit employment discrimination on a wide range of grounds, including race, ethnic origin, gender, and religion were contained in the Race Relations Act 1971 and the Human Rights Commission Act 1977, as well as in the personal grievance provisions of the Industrial Relations Act 1973 (subsequently incorporated in the Labour Relations Act 1987 and in the Employment Contracts Act 1991). However, the impact of these three acts was limited. A series of court decisions limited the jurisdiction of the statutory personal grievance provisions, to the point where most personal grievances were concerned with claims of unjustifiable dismissal. Wider issues of personnel policy - recruitment, selection, promotion and so forth - could not be addressed satisfactorily. Nor could these be addressed through the anti-discrimination legislation, which focused on specific individual complaints of discrimination, mostly confined to hiring decisions. There was no statutory obligation on employers to adopt equal opportunity policies, and no effective means of ensuring changes to personnel policies to protect the collective interests of disadvantaged groups.

Government officials, not politicians, were central to the promotion of the EEO agenda. Politicians from the governing National Party did not support EEO, but nor did they oppose it. An informal coalition of supportive managers and trade union officials advanced the issue industrially. A number of important EEO provisions were introduced throughout the public sector. These included permanent part-time work, the right to return to employment after up to five years of child care, enhanced domestic leave and a right to tangihangi leave. The same coalition succeeded in convincing the State Services Commission (SSC), the central employing authority of all government employees, to issue an EEO Policy Statement in 1984 which recognised the under-representation of women, Maori, Pacific Island people and people with disabilities in the public sector, and called upon government departments to address this through the adoption of EEO policies (Tremaine, 1991: 347). Over the next two years, EEO gradually became articulated as an issue in the public sector. Awareness of the issue grew, new supporters slowly emerged, both within and outside government departments, and, crucially, resources were committed. As Tremaine observes "... in less than two years, an EEO co-ordinator had been appointed within the SSC, a network of senior liaison officers had been established covering all departments, and some departments had appointed their own internal EEO co-ordinators" (1991: 348). Tremaine notes that during 1986, an EEO Unit was established within the SSC, with specialist officers to act as advocates in the public sector for the target groups - women, Maori, other ethnic minorities, and workers with disabilities. Tentatively, and unevenly, EEO was becoming established institutionally in the public sector. 


\section{EEO encounters managerialism: the State-Owned Enterprises Act, 1986}

At about this stage, the new EEO constituency encountered the agenda of managerialist restructuring for the first time. Managerialism was a major component of a radical state restructuring programme embarked upon by the Labour Government elected in 1984. This programme involved extensive privatisation, comprehensive reorganisation of government departments, social services and the health and education sectors, as well as a programme of corporatisation, in which most of the state's trading functions were established in autonomous commercial enterprises (Boston, et al., 1991).

According to the Treasury, the major force for public sector reform, most public sector organisations had neither clearly defined goals nor a management plan. They lacked procedures to assess either individual or organisational performance, and were, in general, concerned with input controls rather than output measurement. Poor public sector performance was attributed to the stultifying impact of rigid forms of bureaucratic control. Managerialism looked instead for structures which encouraged the exercise of managerial discretion and flexibility and encouraged adaptability to changing circumstances (Treasury, 1984, 1987; Scott, Bushnell and Sallee, 1990).

An early target for the restructuring programme was the state's trading sector. This became the first arena in which EEO and managerialism clashed directly. The Government believed that the unsatisfactory commercial performance of its trading sector over many years stemmed from confusion between their commercial and non-commercial objectives, and the related intrusion into management decision-making of political considerations. The StateOwned Enterprises (SOE) Act 1986 established a number of trading departments as commercial enterprises. The SOEs were to be independent of the Government, and were obliged by their legislation to operate as efficiently as enterprises not owned by the Crown. Fears were expressed, however, that commercial pressures on the new corporations would lead them to abandon their traditional social responsibilities and the employment practices characteristic of the public sector. There was particular concern that recent advances made in the EEO area would be rolled back. EEO and social responsibility concerns were not part of the managerialist agenda. They were antithetical to the commercial objectives of the SOEs, and the requirement that they model themselves on their private sector counterparts. These had no social or EEO obligations to meet. But the prior establishment of the EEO agenda within the public sector, the committal of resources to it and the existence of influential internal and external supporters ensured that these concerns could not be easily dismissed.

Common ground, or at least a compromise between the two agendas, was found in the liberal model of EEO. The latter could be made compatible with managerialism by highlighting their twin concerns with efficiency. Managerialism looked for the efficient operation of different markets, and if the labour market could be made more efficient by the elimination of discriminatory practices, then managerialism was able to accept EEO. Thus, the advocates of EEO relied heavily upon its claimed contribution to labour market efficiency. In particular, they emphasised its ability to widen the recruitment pool to include people with a range of knowledge, skills and experiences different from those which 
had traditionally predominated in the public sector, but which would become increasingly important to the efficient and effective delivery of public services in the future.

But only a limited version of EEO was politically and bureaucratically sustainable in the State-Owned Enterprises Act 1986. Managerialism ruled out any tight EEO obligations upon SOE chief executives. If EEO enhanced labour market efficiency, then rational chief executives would implement EEO policies themselves. Moreover, managerialism could not tolerate any limiting of managerial discretion by way of specific definition of what had to be included in an EEO programme or methods for its implementation. Thus, the approach taken was purely exhortatory. The Government included in the SOE Act a requirement that the SOEs be "a good employer". This included a requirement that they take account of social responsibilities, but only where practicable, and that they implement an equal employment opportunities programme. But the latter provision was simply a bald statement. The Act was silent on what constituted the desired structure, objectives, content or operation of this EEO programme, nor did it include any monitoring or enforcement mechanisms. The only way to enforce the good employer obligation was in the courts. In the event, there have been no successful cases concerning EEO brought under the good employer obligation.

\section{EEO in the State Sector Act, 1988}

Within the core public service itself, the EEO agenda continued to advance slowly. By 1987 the SSC had established an EEO Unit and had issued a directive requiring government departments to establish an EEO programme by April 1 1988. This directive was overtaken by the introduction of the State Sector Bill into Parliament in December 1987. The Bill reflected the extension of the managerialist agenda to the remainder of the public sector. Permanent heads of government departments were transformed into chief executives on 5 year contracts. Centralised personnel authority previously wielded by the State Services Commission was devolved to chief executives, who became employers with the power to appoint, promote, discipline and dismiss staff. The merit provisions from earlier legislation were considerably diluted, and appeal procedures against non-appointment were abolished. In keeping with the creation of chief executives as employers, the unified internal public service labour market gave way to separate departments operating largely independently of each other. Staff lost preferential rights of employment in other departments. Subsequent industrial relations changes further enhanced managerial authority. Senior managers were removed from collective bargaining coverage and placed on individual employment contracts. Long-standing salary scales with annual increments for satisfactory performance were replaced by salary ranges. These ranges prescribed only a minimum and maximum salary, with employees to be placed in the range by management on the basis of performance appraisal.

Not surprisingly, the original State Sector Bill did not advance the EEO agenda beyond the liberal model. The Bill simply replicated the EEO provisions in the SOE Act. These had been judged compatible with managerialism in the past, and the experience of the SOEs had not suggested that they greatly constrained managerial discretion. In their first two years of operation, the SOEs had exemplified the crusading zeal of the managerialist agenda. The 
reassertion of managerial authority in the workplace was an explicit and largely achieved objective of corporate strategy (Walsh, 1988; Walsh and Wetzel, 1993). The EEO provisions did not greatly restrain management. The weakness of the good employer obligation limited union ability to retain or improve on existing EEO employment conditions. A number were lost, and the SOEs were not notable for their promotion of EEO concerns.

Thus, the SOE experience had not encouraged confidence in the effectiveness of the liberal model of EEO. Supporters of EEO both inside and outside the public service moved to promote a stronger version of EEO than that contained in the State Sector Bill. Concern over EEO was expressed at two levels. One was the failure of the Bill to provide for the continuation of a wide range of EEO-related employment conditions in the public service. These included provisions for maternity leave (public sector conditions were superior to the statutory minima), sick leave, child-care support, priority employment rights following leave for child-care, flexible hours, permanent part-time work, tangihangi leave and other matters. The second concern was over personnel procedures, including the EEO provisions. The Bill did not require chief executives to advertise vacancies nor to publicise appointments, both major departures from established practice. The Bill replaced the formal definition of merit with a more subjective requirement for the appointment of candidates who "in the opinion of the chief executive" were best suited to a position. Formal service-wide appeal procedures, which allowed an unsuccessful candidate to appeal against non-promotion or failure to be appointed to any position in any department, were replaced by a more informal review, which applied only to unsuccessful candidates from within the department concerned.

By 1987-88, the EEO agenda was industrially and politically stronger in the public sector than it had been in 1986 at the time of the SOE Act. Accordingly, the struggle to improve the EEO-related aspects of the State Sector Bill became central to the public debate over the legislation (Walsh, 1991). Some successes were achieved. The Government agreed to carry forward all existing employment conditions, and established negotiating procedures for their codification. Some personnel provisions were improved. The Act requires chief executives to advertise vacancies and appointments. The requirement for merit-based appointments was improved by dropping the subjective phrase "in the opinion of the chief executive", thereby making it possible for the review procedure to be used to assess whether or not the person "best suited to the position" had been chosen. An important consequence of the debate over the Bill was to widen public, political and bureaucratic understanding of the relevance of fundamental personnel procedures, such as the rules governing the advertising of vacancies, to EEO.

A fierce debate was waged over EEO itself, in which public sector unions, women's groups and other outsiders formed an unspoken alliance with EEO supporters inside the public service. The outcome was a set of EEO provisions which remained consistent with the liberal model, but which represented a considerable strengthening of the original provisions in the Bill, and which in places spilled over into the radical EEO model.

The different emphasis of the State Sector Act was reflected in the criteria for the appointment of chief executives which include an obligation to have regard to the need to appoint chief executives who will promote EEO. Liberalism's emphasis on fair dealing 
based on individual merit is central to the good employer obligation in the Act. The chief executive is enjoined to operate a personnel policy "containing provisions generally accepted as necessary for the fair and proper treatment of employees". These include "the impartial selection of suitably qualified persons for appointment" and an obligation to provide "opportunities for the enhancement of the abilities of individual employees". The Act defines an EEO programme in orthodox liberal terms as "a programme that is aimed at the identification and elimination of all aspects of policies, procedures, and other institutional barriers that cause or perpetuate, or tend to cause or perpetuate, inequality in respect to the employment of any person or group of persons." But even that definition contains a hint of the radical agenda. The reference to the need to remove "institutional barriers" that cause inequality arguably goes beyond the individualist and procedural emphasis of the liberal model.

Other provisions of the good employer obligation draw on the radical model of EEO. The focus on target groups rather than on individuals, which is central to the radical model, is firmly entrenched in the State Sector Act, which identifies Maori, women, ethnic and minority groups and persons with disabilities as the subjects of EEO programmes. Moreover, the radical model's emphasis on labour market outcomes is partially enshrined in the Act's obligation upon chief executives to have regard to the employment requirements of women, Maori and persons with disabilities. A statutory obligation upon chief executives to take account, not just of the labour market needs of the organisation but of the labour market needs of affirmative action target groups, is a clear departure from managerialist principles and from the previously dominant liberal model of EEO. Similarly, if taken at its word, the Act's requirement that EEO programmes take account of the "aims and aspirations" of Maori and ethnic and minority groups forces upon chief executives a set of considerations from outside the organisation which neither managerialism nor the liberal model of EEO would embrace.

\section{Implementing EEO under the State Sector Act, 1988-1992}

EEO Management Plans were decisively tilted towards the liberal model of EEO. The liberal agenda was reflected in EEO provisions which were universal in their application. They involved new rules and procedures or changes to existing rules and procedures designed to put all employees or potential employees on an equal footing so as to ensure that their employment prospects were dependent on relative merit.

The first requirement for the advancement of EEO was to guarantee its status and its resources within departments, and to provide a secure platform from which its supporters could reasonably hope to make progress. There were two aspects to this - the integration of EEO as a management function within management structures, and raising the awareness of and support for EEO among all departmental staff. A perception by management - and by employees - that EEO was imposed from outside and constituted interference with the real business of managing would be certain to stimulate resistance and jeopardise its prospects of success. All EEO Management Plans, therefore, concerned themselves with the question of institutional security. This was expressed in aiming for the appointment of EEO Coordinators at appropriate levels, reporting to or actually part of senior management, and 
the appointment of EEO liaison staff. A key objective in some plans was that all job descriptions for management positions include responsibility for EEO, and that a commitment to EEO be a requirement for management appointments.

In one case, a new department established in 1987, the initial departmental structure did not include a position to deal with EEO responsibilities. The EEO functions were given at different times to two officers in training and personnel. The result was that "the EEO plan was delayed because both officers involved had key roles in dealing with the surplus staffing situation. This work along with their prime functional responsibilities took precedence over all other work". Until an EEO coordinator was appointed in 1989/90, little progress was achieved. In contrast, another new ministry sought consciously to integrate EEO concerns into its work culture from the outset. During the restructuring process which led to its establishment, an EEO Committee was formed to monitor the process and to advise management of EEO issues that needed to be taken into account.

It was also necessary that progress towards EEO objectives, as with any management objectives, be regularly and reliably assessed. Thus, many programmes included as an objective the development of a database on advertising, job applicants, appointments, promotion, disciplining, training, dismissals and redundancies for systematic assessment against the principles of the EEO programme. This particular objective was vulnerable to wider corporate decisions about monitoring human resource outcomes, especially where significant capital investment was required.

The institutional security of EEO, and its prospects of success, depend to an important degree on support from staff throughout the organisation. A range of objectives were identified in departmental plans to raise awareness of EEO. Common elements included publicising the department's commitment to EEO, circulating information packages among employees, banning the use of sexist and racist language in all departmental communications and ensuring that an EEO grievance or complaints process was established and well known. All departments relied upon training as a means of raising awareness. Management Plans included the objective of sending staff at all levels on general EEO courses, and on Maori language and culture courses, and courses on other community languages and cultures.

Undoubtedly the biggest component of all EEO Management Plans dealt specifically with personnel and human resource management policies and practices. The determination to give all individuals of comparable merit a roughly equal chance of being appointed to an organisation and of progressing within it is at the heart of the liberal model of EEO. This concern was expressed in a focus on recruitment, selection, performance appraisal and job evaluation policies. Thus, most departments sought to ensure that all their personnel material reflected their EEO policies, that recruitment booklets were multi-lingual and that recruitment methods were culturally appropriate. This involved advertising jobs widely to affirmative action target groups inside and outside the department, noting in all job advertisements the department's commitment to EEO and its desire to receive applications from target group members, and, where appropriate, advertising vacancies in Maori and other languages and including in job advertisements knowledge of Maori and community languages and cultures as part of the criteria for appointment and promotion. In some cases, it also entailed establishing relations with community groups which might be a source of potential job applicants. 
The EEO Plans called for job interview panels with an appropriate gender and cultural balance. Some aimed to provide suitable EEO training for all interview panel members to ensure they were free of bias in their questions and evaluations of applicants. All plans permit job applicants to bring whanau (a support group) to interviews. Many plans addressed the need for a physical audit of the workplace to assess its suitability for people with disabilities, and to make such provision, including carparking, as was necessary. Some plans emphasised the importance of incorporating EEO indicators into any performance appraisal system and called for the review of job descriptions and job evaluation systems to ensure they were gender and culturally neutral, and that they specify appropriate and essential job content, relevant experience and skills. In this regard, there was particular concern not to disqualify unnecessarily workers with disabilities and to identify jobs that could be carried out by workers with disabilities.

In contrast to the liberal model, the provisions in the plans which drew on the radical model were selective. They involved direct intervention in an effort to alter labour market outcomes for affirmative action target groups. The provision of career development opportunities specifically for target group members was an important example of this approach. This included career counselling, with counsellors drawn from target groups where possible. Deliberate efforts were to be made to solicit target group members for nontraditional jobs, and to introduce career structures in previously dead-end jobs. In the debate over EEO, positive discrimination policies are the most well known examples of this interventionist approach. Departments were slow to move towards positive discrimination policies, partly no doubt due to fears of political repercussions, but also because of scepticism about their effectiveness. However, by the third set of plans in 1990/91, there was a visible trend from a liberal to a radical perspective, expressed in quantitative targets for the employment of target group members. Other departments were committing themselves to employing "more" target group members. Related to this was the objective of nominating target group members for management training and systematic programmes to encourage promotion applications from group members. Another interventionist or redistributive policy was departmental support for existing State Services Commission affirmative action programmes for target groups. Within the nine departments, the degree of support for these programmes was mixed.

However, these approaches, while fitting into the radical model, by and large do not challenge the structure of the organisation in any fundamental sense. They are strategies to fit members of target groups better for the requirements of the organisation. An alternative approach is to rethink the broader issue of workplace organisation. This involves an acceptance that the success of EEO policies may require changing the organisation as much as changing the individuals it employs. In this vein, some departmental EEO Plans included the objective of investigating the possibilities of creating more flexible work patterns. This included numerical flexibility - flexible hours, permanent part-time work, job sharing, rotation, secondment, special projects or placements in positions of greater responsibility, and child-care policy - and functional flexibility occupational reclassification, reskilling target group members into non-traditional areas, new ways of defining and recognising skills, especially those acquired in home, marae, community work or other non-traditional environments. The plans also included the objective of applying affirmative action policies in selecting workers for training and reskilling opportunities. 
Potentially, these are the most radical of the provisions in the EEO Plans. They alone spill over into Cockburn's transformational project, being based on the notion that the traditional ways of organising work, of recognising and valuing skill and experience and of structuring work flows are in need of redesign. This approach begins from the premise that the organisation of the labour process, in all its dimensions, is the most fundamental aspect of any organisation, and shapes the range of individuals likely to be able to enter and to prosper within it. Organisations are made and remade in the image of those who have succeeded in them. Developing new winners demands a different kind of organisation. It is the most radical and challenging component of the EEO agenda.

\section{Assessing EEO in the public sector, 1988-92: liberalism ascendant}

The tension in the State Sector Act between the liberal and radical EEO agendas was largely resolved in favour of liberalism. It is clear that the principal thrust of the EEO Management Plans of the departments in this study was to reform personnel and human resource management practices and policies in a manner consistent with the liberal model of EEO. As discussed earlier, the liberal model could be hitched to the managerialist cause, and presented as contributing to greater organisational efficiency by removing obstacles to a freely operating labour market. This would ensure that organisations drew upon the widest possible pool of potential recruits and that the contribution they were able to make once employed was not negated by bias in personnel and human resource management procedures, nor by the personal prejudices or ignorance of supervisors and managers.

Nonetheless, the injection into the State Sector Act of aspects of the radical model led to the inclusion in EEO Management Plans of objectives and policies that went beyond liberalism and reflected radical concerns. It is important to note that this was made possible by the wording of the State Sector Act, itself a product of prevailing political, industrial and bureaucratic alliances. Without this, the Act would not have opened the door to the radical model of EEO. However, the wording of the Act was a necessary but not sufficient condition for the inclusion of radical provisions in the EEO Plans. Their inclusion depended upon a range of factors. As Messervy (undated) has shown, the women appointed as EEO coordinators tended to support the radical model of EEO, but recognised the political limits to what could be achieved. Nonetheless, they became an independent force for a cautious shift towards the inclusion of components of the radical model in the plans.

Moreover, as Jewson and Mason (1986) observe, support for the radical model may come from liberals. They suggest that liberals may employ radical language, and promote positive discrimination in response to the failure of positive action policies, in order to stimulate progress towards those positive action goals. Thus, it is not clear whether the new found emphasis upon the radical agenda in the later plans, expressed in a focus on outcomes for target groups, is a genuine commitment, or an example of what Jewson and Mason refer to as the deliberate ambiguity of language often used in the EEO debate. Alternatively, and ironically, it may result from the influence of managerialism itself, rather than from any support for the radical agenda. Managerialism tends towards setting quantitative objectives in order that achievement and non-achievement can be clearly 
measured. It is possible that managerialist frustration at the lack of clarity about liberal EEO objectives ("advertise more widely", "raise EEO awareness", "send more staff on EEO training courses") leads to the establishment of quantitative targets for EEO as for other management policy objectives.

This assessment focuses on the reasons why the liberal EEO agenda came to predominate over the radical and transformational models in departmental plans. As interesting, however, is the manner in which the fate of those plans was shaped by the institutional context in which they were designed and implemented. The three most important aspects of this context were public sector restructuring and fiscal restraint, the introduction of new management structures and, thirdly, the disintegration of the alliance that had previously advocated the EEO agenda.

Continual restructuring on a massive scale throughout the New Zealand public sector (Boston, et al., 1991) shaped the environment for EEO. Managerialism was a driving force for this restructuring, as first the Labour and then the National Government sought to achieve substantial efficiency gains in the operation of the public sector. Departments were abolished and new ones set up. Others were reorganised internally. Services were variously commercialised, contracted out, privatised and reallocated among agencies. Many functions of the central state were devolved to regional or local government. There were huge job losses. Job insecurity pervaded all levels of the public sector. Fundamental changes were made to management structures and modes of operation. Financial and human resource management were comprehensively changed (Pallot, 1991; Walsh, 1991). Secondly, all government agencies encountered fiscal stringency to a degree not previously known. Budget constraints cramped departments and compelled economy in all aspects of their operations.

Time and again, departmental progress reports identified restructuring and financial restraint as the key constraints on the achievement of EEO objectives. Organisational turbulence and continuing uncertainty made it difficult to implement new EEO policies effectively. This was particularly so for policies, such as career development and training, which required managers to take a long-term perspective. Few could do this with much confidence. In a period of great job insecurity, personnel policies which seemed to favour particular groups over others aroused opposition. Fiscal constraint made some managers reluctant to allocate scarce and prized resources to what they saw as unnecessary and unproductive activity. It is likely that departments on occasions found these to be convenient scapegoats for lack of success, but there can be little doubt that the task of advancing EEO in the New Zealand public sector in these years was made far more difficult by the relentless process of reorganisation and financial restrictions.

The impact of restructuring was most marked in areas drawn from the radical and transformational models. Departments either gave a greater priority to the achievement of objectives from the liberal model, or genuinely found these easier to achieve. Continual restructuring particularly affected training initiatives for target groups and ensured the perpetuation of historical patterns of labour market discrimination. Many Maori and Pacific Island staff in the department were in lower grades, and with basic grade positions being cut back, a number of Maori and Pacific Island staff were made redundant. 
New organisational structures established as part of the restructuring process had a distinctive impact on the fate of EEO. Responsibility for EEO, as for other management functions, was decentralised. At one level, the State Sector Act diffused responsibility out from the SSC as the central employing authority to the chief executives of individual departments. Secondly, some departments established a multi-divisional structure. Where the divisions had a substantial measure of autonomy, EEO responsibility was assigned to the various divisions. It remains a moot point whether direction from the centre under the pre-1988 structure might have achieved more and at a faster rate than working through separate and autonomous departments and divisions. The old structure had essentially one crucial veto point, and a change in the prevailing balance at the centre could have brought progress to a sudden halt. The new structure is more favourable to EEO when a particular department or division is strongly supportive, and can move ahead at its own pace and according to its own judgement. It is less favourable to EEO when the opposite is the case. The creation of a greater number of potential veto points enhances the opportunities for successful resistance to EEO. Clearly, decentralisation has made for greater variation in EEO policies and practices. The range of departmental plans attests to that. But, in the case of some departments with autonomous divisions or service units, the differences among the EEO plans are quite marked, and hence EEO outcomes may be notably uneven within a department.

\section{The disintegration of the EEO alliance?}

The promotion and consolidation of the EEO agenda in the New Zealand public sector depended upon a particular balance of political, bureaucratic and industrial coalitions. Shifts in the balance of those coalitions have gravely undermined the prospects for continued advances in EEO.

Politically, a neutral National Government in the first half of the 1980s allowed the latter two parties to the EEO coalition - government and union officials - to take the initiative and make significant advances. National was followed by a Labour Government, which although committed to managerialist reform, came under pressure from supporters of employment equity, who were key members of its political alliance and, in many cases, strategically well placed to influence government policy (Wilson, 1992). Labour's ambivalence and internal divisions over the issue of employment equity were resolved, in the case of EEO, by support for the liberal model. In the case of equal pay for work of equal value, Labour prevaricated throughout its term in office, until belatedly passing the Employment Equity Act in 1990, just prior to the election. The Employment Equity Act provided for the phased introduction of EEO programmes throughout the private sector which previously had escaped any statutory obligations to implement EEO policies. The Act also provided for the taking of comparable worth or equal pay for work of equal value claims. The repeal of that Act by the National Government shortly after the election signalled the loss of what political support there had been for the employment equity agenda.

It became increasingly clear following the repeal of the Employment Equity Act that EEO was a lower priority for the National Government priority than it had been for Labour. 
In turn, that clarified the degree to which the impetus for EEO had depended upon even the limited measure of political support for EEO under Labour. Without that support, and notwithstanding the continuing statutory obligation to be a good employer, EEO was seen to be precariously based within the public sector. The impetus for EEO did not disappear but it perceptibly weakened.

Similarly, government officials, the second party to the EEO alliance, became less well placed to promote EEO. In part, this was due to restructuring. The continual process of restructuring made it difficult for most EEO supporters to continue to address themselves to it. Official responsibility lay with the EEO Section in the State Services Commission, but as discussed earlier, the decentralisation of responsibility for EEO reduced the capacity of supportive government officials to influence the course of events from the centre. Moreover, despite the State Services Commission's statutory obligation to "promote, develop and monitor" EEO, an active role for the EEO Unit would have gone beyond the new kind of relationship that was emerging between the central agency and government departments. There was a deliberate effort in general to discard most of the control historically exerted by the Commission, and it was not intended that EEO should be exempt from that. In any event, the Commission also had responsibility for reviewing the performance of chief executives, and, it was argued, in this review function it would be able to place considerable emphasis upon the degree to which they had implemented their EEO programmes. Very recently the resources of the EEO Section have been increased and it remains to be seen whether this is the precursor of a different and more active approach from the centre.

Public sector union officials, the third party to the informal alliance that had previously promoted EEO, also found it difficult to give EEO the priority it had previously enjoyed. Union officials were increasingly preoccupied with the consequences of restructuring - job losses, redundancies, departmental reorganisations, loss of services and so forth. Union officials had also to deal with employer pressure on established conditions of employment. As part of its effort to establish a managerialist culture, the State Services Commission mounted a campaign to reverse a wide range of existing conditions of employment. These pressures from restructuring and over the preservation of employment conditions crowded in on union officials. They were faced with new demands from their members, in which EEO did not figure highly. This made it much more difficult for them to give the same degree of attention to EEO as in the past. Managerialism had another impact on EEO by making it more difficult to sustain the cooperation between union and government officials which had been so important to the progress of EEO previously.

From late 1990, union officials were preoccupied with first resisting and then coping with the National Government's industrial relations legislation, the Employment Contracts Act. In retrospect, it is apparent that the substantial commitment public sector unions were able to make to the promotion of EEO reflected the relative absence of competing demands upon their resources in the calmer industrial atmosphere prior to the State Sector Act 1988 . Ironically, just as the State Sector Act appeared to signal a maior victory for EEO, it also reflected and gave further impetus to other industrial relations changes that would severely restrict union ability to continue to support EEO. 
The loss of momentum from earlier supporters placed a great responsibility upon EEO coordinators in government departments. They, however, were also in a difficult situation. They faced the usual difficulties of promoting a relatively new agenda in a bureaucratic setting where possibilities for resistance and opposition abound. In addition, they were required to do so amidst a process of managerialist restructuring whose very premises were often hostile to EEO. Messervy's study (undated) of EEO coordinators in government departments found that although most of them held to the radical model of EEO, the majority of the measures they had implemented fitted into the liberal model. Messervy suggests this was because the co-ordinators saw liberal measures as having a greater chance of being effective.

EEO co-ordinators are caught in the middle of demands for EEO and expectations from senior management that they will support and promote wider organisational objectives. As Cockburn puts it, EEO officers operate as "an interface between a particular constituency of interests and the management system". They are like community officers in local authorities. "If they do the job to the benefit of their constituency they incur the wrath of their employers. If they satisfy their managers they will certainly be blamed for treachery by those they hoped to assist. Both jobs attract progressives and both jobs destroy them" (p. 218).

\section{A future for EEO}

In such difficult circumstances, where key supporting alliances have been disrupted by wider developments, and where new and potentially effective alliances are not immediately apparent, it is not surprising that a sense of gloom pervades many of the assessments of the fate of EEO in the New Zealand public sector. But much of the gloom stems from a misunderstanding of why EEO does not continue to advance. The recent report of the EEO Section of the State Services Commission concludes that " ... not all organisations have heard or absorbed the message that progress in EEO is integral to the practice of good human resource management. (State Services Commission, 1992: 17). In this analysis the real difficulty is seen as a cognitive one. It lies in the perverse inability or unwillingness of human resource managers to appreciate the value of EEO. The analysis presented here suggests that the problem has more to do with the prevailing balance of industrial and political coalitions. The lack of progress is embedded in the institutional context of EEO in the public sector in recent years and the break-up of the alliances which had nurtured and promoted it. Those allies had advanced the cause of EEO by hitching the liberal model of EEO to the managerialist agenda, despite the tensions between the two. But the undermining of the EEO alliances by wider changes in the structure and operation of the public sector made it increasingly difficult to sustain the link between EEO and managerialism. The present and future fate of EEO is bound up less in the ability of human resource managers to understand what EEO can do for their organisation than it is in the reconstruction of powerful alliances in its support.

The unlikelihood of this occurring in the immediate future may justify the current pessimism about EEO in the New Zealand public sector. A different perspective would argue that the promotion of EEO is a long-term project, and that an exclusive preoccupation 
with current difficulties obscures progress made in the last decade. Most importantly, what matters is the acquisition of resources and the embedding of EEO programmes in government departments, however unevenly and in some cases very tentatively. Defending a beachhead may seem a modest objective; but successful defence offers the prospect of future progress.

\section{References}

Adams, D. (1990), Equal Employment Opportunity and Moral Reasoning in Policy Analysis, Unpublished paper, University of Tasmania.

Boston, J., Martin, J., Pallot, J., and Walsh P. (eds) (1991), Reshaping the State: New Zealand's Bureaucratic Revolution, 1984-1990, Auckland, Oxford University Press.

Cockburn, C. (1989), Equal Opportunities: The Long and Short Agenda, Industrial Relations Journal, 20(3): 213-225.

Hamid, R. (1992), Equal Opportunities in Crisis, The EEO Practitioner, Newsletter of the EEO Practitioners Association, 2: 4.

Jewson, N. and Mason, D. (1986), The Theory and Practice of Equal Opportunities Policies: Liberal and Radical Approaches, Sociological Review, 34(2): 307-334.

Messervy, P. (undated), Equal Employment Opportunities: A Strategy for Radical Change or a Screen for Liberal Justice?, Unpublished paper, Wellington.

Pallot, J. (1991), Financial Management Reform. In Boston, J., Martin, J., Pallot, J., and Walsh P. (eds), Reshaping the State: New Zealand's Bureaucratic Revolution, 1984-1990, Auckland, Oxford University Press.

Poiner, G. (1991), On Its Own Merit: Limits to the Effectiveness of Equal Employment Opportunity. Paper presented to a seminar on Human Resource Management and Industrial Relations in the Public Sector, Centre for Australian Public Sector Management, Griffith University, Brisbane, November 29-30.

Scott, G., Bushnell, P. and Sallee, N. (1990), Reform of the Core Public Sector: New Zealand Experience, Governance, 3(2): 138-167.

State Services Commission (1992), Equal Employment Opportunities: Progress in the Public Sector as at June 1991, Wellington, EEO Section, State Services Commission.

Sullivan, M. (1991), From Personal Tragedy to Social Oppression: The Medical Model and Social Theories of Disability, New Zealand Journal of Industrial Relations, 16(3): 255-272. 
Tremaine, M. (1991), Equal Employment Opportunity and State Sector Reform. In Boston, J., Martin, J., Pallot, J., and Walsh P. (eds) Reshaping the State: New Zealand's Bureaucratic Revolution, 1984-1990, Auckland, Oxford University Press.

Treasury (1984), Economic Management, Wellington, Treasury.

Treasury (1987), Government Management, Wellington, Treasury.

Walsh, P. (1988), The Struggle for Power and Control in the New Corporations: The First Year of Industrial Relations in the State-owned Enterprises, New Zealand Journal of Industrial Relations, 13(2): 179-190.

Walsh, P. (1991), Industrial Relations and Personnel Policies under the State Sector Act. In Boston, J., Martin, J., Pallot, J., and Walsh, P. (eds) Reshaping the State: New Zealand's Bureaucratic Revolution, 1984-1990, Auckland, Oxford University Press.

Walsh, P. and Wetzel, K. (1993), Preparing for Privatization: Corporate Strategy and Industrial Relations in New Zealand's State-owned Enterprises, British Journal of Industrial Relations, forthcoming.

Webb, J. and Liff, S. (1988), Play the White Man: The Social Construction of Fairness and Competition in Equal Opportunities Policies, Sociological Review, 36(3): 532-550.

Wilson, M. (1992), Employment Equity Act 1990: A Case Study in Women's Political Influence, 1984-90. In Deeks, J. and Perry, N. (eds), Controlling Interests: Business, the State and Society in New Zealand, Auckland, Auckland University Press. 